\title{
Karayolu Trafik Güvenliği 'ne Yönelik Gerçekleştirilen Sosyal Kampanya, Denetim, İdari Cezalar ve Bireyler Üzerindeki Etkileri
}

\author{
Ozan Kavsirac1 ${ }^{1}$ \\ ORCID: 0000-0001-6351-3725
}

\author{
Mehmet Demirbaş² \\ ORCID: 0000-0002-9760-1130
}

\author{
Sena Tine ${ }^{3}$ \\ ORCID: 0000-0002-9526-0176
}

\section{$\ddot{\mathrm{O} z}$}

Karayolu, günümüzde insanların ve eşyalarm konforlu, verimli ve güvenli bir şekilde taşınmasında en çok tercih edilen ulaştırma sistemlerinden biridir. Bu nedenle trafik güvenliğinin să̆lanmaması durumunda yaşanması muhtemel trafik kazaları, bireyler, toplumlar ve devletler açısından maddi ve manevi önemli kayıplara neden olmaktadır. Karayolu trafik güvenliği; insan, araç ve çevrenin etkileşimi sonucunda ortaya çıkması muhtemel sorunları önlenmesine yönelik çok sayıda kurumun dâhil olduğu, sosyal, teknik, yasal ve uygulamalı çalışmaları kapsamaktadır. Trafik güvenliğini tehlikeye düşüren ve trafik kazalarına neden olan unsurlar içerisinde insan etkisinden kaynaklanan faktörler, yüksek bir etkiye sahiptir. Bu çalışmada; karayolu trafik güvenliğini tesis etmek için uygulanan sosyal kampanyalar, denetimler, idari para cezaları ve bu uygulamaların bireyler üzerindeki etkisi araştırılmıştır. Bu çerçevede kısa vadede; trafik denetimleri ve idari para cezaları trafik güvenliğinin sağlanmasında bireylerin davranışları üzerinde daha etkili olurken, uzun vadede bir trafik kültürü oluşturulması kapsamında sürekli tekrar eden sosyal kampanya ve kamu spotlarının daha etkili olduğunu söylemek mümkündür. Ancak her durumda karayolu trafik güvenliği uygulamalarını, bütüncül ve tüm paydaşlarla iş birliği içerisinde birbirini destekleyerek gerçekleştirilmesi gerekmektedir.

Anahtar Kelimeler: Karayolu trafik güvenliği, trafik kazaları, sosyal kampanyalar, trafik denetimleri

\footnotetext{
${ }^{1}$ Dr. Öğr. Üyesi, Polis Akademisi, E-mail: ozankavsiraci@gmail.com

${ }^{2}$ Arş. Gör., Polis Akademisi, E-mail: mehmetdemirbas88@gmail.com

${ }^{3}$ Psikolog, Polis Akademisi, E-mail: sena.tine11@gmail.com

idealkent @ C Kent Araştırmaları Dergisi (Journal of Urban Studies)

http://idealkentdergisi.com
}

Geliş Tarihi Received Date: 24.10.2021 Kabul Tarihi Accepted Date: 27.12.2021 


\title{
Social Campain, Traffic Control, Traffic Penalties Which is implemented for Road Traffic Safety and Effections of Individuals
}

\author{
Ozan Kavsiraci ${ }^{4}$ \\ ORCID: 0000-0001-6351-3725
}

\author{
Mehmet Demirbaş 5 \\ ORCID: 0000-0002-9760-1130
}

\author{
Sena Tine ${ }^{6}$ \\ ORCID: 0000-0002-9526-0176
}

\begin{abstract}
Highway is one of the most preferred transportation systems for people and goods to make transportation comfortable, efficient and safety. Therefore, if an accident occurs due to the absence of traffic safety, it may cause significant material and moral losses for individuals, societies, and states. Road traffic safety consist of social, technical, legal, and applied studies involving institutions for the prevention of possible problems that may arise because of the interaction of people, vehicles, and the environment. Human affect which causes traffic accidents and endanger traffic safety, is the most important impact. In this study, social campaigns, audits, fines for people violating rule at traffic applied to establish road traffic safety and the effects of these practices on individuals were researched. For this purpose, while traffic audits and fines are more effective on the behavior of individuals in ensuring traffic safety for the short term, it is possible to say that repetitive social campaigns and public spots are more effective within the scope of creating a traffic culture. In any case, road traffic safety practices should be applied holistically and in cooperation with all institutes, supporting each other.
\end{abstract}

Keywords: Road traffic safety, traffic accidents, social campaigns, traffic inspections

\footnotetext{
${ }^{4}$ Asst. Prof., Police Academy, E-mail: ozankavsiraci@gmail.com

${ }^{5}$ R.A., Police Academy, E-mail: mehmetdemirbas88@gmail.com

${ }^{6}$ Psychologist, Police Academy, E-mail: sena.tine11@gmail.com

idealkent @ C Kent Araştırmaları Dergisi (Journal of Urban Studies)

http://idealkentdergisi.com
}

Geliş Tarihi Received Date: 24.10.2021 Kabul Tarihi Accepted Date: 27.12.2021 


\section{Giriş}

21. yüzyılda bilgi, iletişim ve ulaşım teknolojilerinde yaşanan gelişmeler, insanların yaşam formlarını ve standartlarını derinden etkilemiş, özellikle kentlerde yaşayan insanların, trafik ve trafik güvenliği konularıyla yüzleşmelerine sebep olmuştur (Alat, 2014, s. 1). Günümüzde trafik kompozisyonunda her geçen gün yeni gelişmelere tanık olmaktayız. Kentlerde nüfus artarak yerleşim yerleri ile iş, okul ve sosyal faaliyet merkezleri arasında uzaklaşma eğilimi gözlemlenmekte, uzaklaşma eğiliminin yanı sıra trafikte insanların bireysel ulaşım niyetinde de sürekli bir artı̧ olmaktadır. İnsanların bireysel ulaşım isteği, araç sayısını ve beraberinde de trafik kazalarındaki artışı tetiklemektedir. Savunmasız yol kullanıcıları olan insanların, iyi eğitilmiş ve bilgilendirilmiş olsalar da trafikte her an hata yapmaları mümkündür. Çünkü insanların yoğunlaşma ve konsantre olma süreleri sınırlıdır. İnsan hataları sonucu gerçekleşebilecek olası trafik kazları, insanlar için hayati riskler taşımaktadır. Bu sebeple trafikte insan unsurunun denetimi ve davranışlarında olumlu yönde değişiklik sağlamaya ve yönlendirmeye yönelik politikalar önem kazanmaktadır.

Karayolu ulaşım sisteminin temel amacı insanları ve eşyaları, verimli ve güvenli olarak bir yerden diğerine taşımaktır. Ancak trafik güvenliğinin yeterli düzeyde sağlanamadığı durumlarda yaşanan trafik kazaları sonrası ortaya çıkan maddi ve manevi faturalar hem bireyler hem de toplum açısından çok yüksek boyutlara ulaşmaktadır (Yasak ve Kılıç, 2014, s. 30). 1896 yılında Londra' da karşıdan karşıya geçmekte olan bir yayaya araç çarpması sonucu meydana gelen ilk ölümlü trafik kazasından sonra milyonlarca insanın trafik kazalarında ölmesi veya sakat kalması, trafik kazalarını tüm dünyada başlıca küresel sağlık sorunlarından birisi haline getirmiştir. Dünya Sağlık Örgütü (DSÖ) raporuna göre, trafik kazası sonucu hayatını kaybedenlerin sayısı 2000 yılında 1,15 milyon kişi iken 2020 yllında 1,35 milyon kişiye yükselmiştir. 100 bin kişiye düşen ölüm sayısı 2000 yılında 18,8 kişi iken 2020 yılında artan nüfus ve taşıt sahipliğine rağmen bu sayı gerilemiştir. Bu durum mevcut durumun daha kötüye gitmediğini gösterse de Birleşmiş Milletlerin (BM) sürdürülebilir kalkınma hedeflerinden biri olan 2020 yılına kadar 2011 yılında meydana gelen trafik kazası kaynaklı ölümlerin \%50 oranında azaltılması hedefinden oldukça uzaktır. Aynı süre zarfinda 100 bin araca düşen ölüm sayısı 134'ten 64'e gerilemiştir. Tüm yaş gruplarının ölüm nedenlerine bakıldığında trafik kazası kaynaklı ölümler 8. sırada, 5-29 yaş grupları arasında ise 1. sırada yer almaktadır (Dünya Sağlık Örgütü [DSÖ], 2018, s. 4-5). Diğer bir ifadeyle trafik kazaları doğal afetlerden daha fazla can ve mal kaybına neden olan bir sorun haline gelmiştir. 
Nitekim Türkiye'de son on yılda depremlerde yaklaşık 20.000, trafik kazalarında ise, 60.000 kişinin hayatını kaybetmiş olması bunun en güzel örneğini oluşturmaktadır.

Karayolu trafik güvenliği çalışmaları, insan, yol ve taşıtın birbiriyle etkileşimi sırasında oluşan sorunlara çözüm yolları arama ve sorunların oluşmasını önlemeye yönelik öneriler geliştirme amacıyla yapılan, eğitim, denetim, yasal düzenleme ve mühendislik çalışmalarını kapsamaktadır (Ekici, 2014, s. 6). Bu kapsamda, birçok kurum veya kuruluş karayolu trafik güvenliğinin sağlanması için çalışmalar sürdürmektedir. Bununla birlikte trafik kazalarının önüne maalesef geçilememektedir. Bunun nedeni ise kazalara neden olan çok farklı faktörlerin bulunmasıdır. İlgili literatürde trafik güvenliğini tehlikeye düşüren ve trafik kazalarına neden olan unsurlar dört başlık altında toplanmaktadır (Furan, 2019, s. 37-38). İnsan etkisinden kaynaklanan faktörler; aracı üreten ve çevreye hükmedenin insan olduğu düşünülürse, trafik kazalarınn büyük bir kısmının insan faktöründen kaynaklandığı görülmektedir. 2918 Sayılı Karayolları Trafik Kanunu'nun 84. maddesinde kazaya sebep olan sürücülere ait asli kusurlar belirtilmiştir. Sürücülerin; kırmızı 1şıkta geçmesi, taşıt girmesinin yasak olduğu yollara girmesi, arkadan çarpma, geçme yasağı olan yerlerde geçme, şerit ihlali, kavşaklarda geçiş önceliğine uymama vb. sebeplerden kaynaklanmaktadır. Yolcu kusurları ise; taşıttan sarkmak, taşıt hareket halindeyken binmek ve inmek, taşıt içinde hareket halindeyken hareket etmek ve açık yük üzerinde hareket etmek vb. nedenlerden kaynaklanmaktadır. Yaya kusurları ise; kırmızı ışıta geçmek, yola aniden atlamak, duran aracın önünden ya da arkasından geçmek, yol ortasında yürümek, hareket halindeki taşıta binmek vb. nedenlerle yaya kusurları sonucu kazalar meydana gelmektedir.

Yol yapısı ve çevrenin etkisinden kaynaklanan faktörler; altyapı olarak da adlandırılan yol ve çevre faktörü açısından; yolun fiziksel özelliklerinin elverişsiz olması trafik kazalarında önemli rol oynamaktadır (Demiröz, 2006, s. 19-20). Trafik güvenliği açısından kazaların oluşmasını engellemek ya da oluşan kazalarda zararın az olmasını sağlamak için altyapıyla ilgili çalışmalar yapılması önemli bir unsurdur. Çevre koşulları da trafik kazalarını oluşmasına neden olan bir faktördür. Örneğin yağmur, kar yağışı, sis ve bunlar gibi meteoroloji olayları, araç sürücülerinin görüş mesafesini ve araçların yola tutunmasını olumsuz yönde etkiler ve trafik güvenliğini de tehlikeye düşürmektedir.

Araç etkisinden kaynaklanan faktörler; Türkiye taşıt merkezli bir trafik sistemine sahiptir. Kazalar hangi kusur sonucu oluşursa oluşsun mutlaka taşıtlarla yapılmaktadır. Taşıtlar, üretimden hemen sonra teknik olarak hatasız bir şekilde teslim edilmekte, zamanla kullanımından dolayı taşıtlarda yıpranma 
ve teknik arızalar çıkmaktadır. Bununla birlikte araçların gerekli bakımlarının zamanında yapılmaması da teknik arızalara yol açabilir. Teknik olarak trafiğe çıkmaya hazır olmayan araçlar ise, karayolu trafik güvenliği açısından önemli bir tehdittir. Bu durum trafik kazalarının oluşumunda etkili olmaktadır (Demiröz, 2006, s. 18).

Yasal ve yönetsel faktörler; trafik güvenliğinin sağlanması noktasında, hukuki uygulamalar ayrı bir öneme sahiptir. Ülkemizdeki yasal mevzuatta Karayolu trafik güvenliği (Karayolu Güvenliği Yüksek Kurulu Kuruluş, Görev ve Çalışma Yönetmeliği) "Can ve mal kaybı ve trafik kazalarını önlemek amacıyla; yayaların, hayvanların ve araçların karayolu üzerindeki hal ve hareketlerinin tanzimi ile bu konuda verilerin toplanması ve değerlendirilmesini ifade eder." şeklinde belirtilmektedir. Trafik ile ilgili yasa ve kuralların ülkemiz şartlarına uygun olması, uygulamaların iyi bir denetim mekanizmasıyla denetlenmesi, ceza uygulamalarının caydırıcı olması trafik düzeninin sağlanması için çok önemlidir. Trafik güvenliğinin geliştirilmesinde ihtiyaçlara cevap verecek şekilde uygulanabilir kuralların olması olumlu etki yapar (Demiröz, 2006, s. 20). Yukarıda verilen ve trafik kazalarına neden olan faktörler arasında Türkiye İstatistik Kurumu (TÜİ) 2020 verilerine göre sürücü kusurları, \%88 oranı ile birinci sırada yer almaktadır (Türkiye İstatistik Kurumu [TÜİK], 2020). Bununla birlikte, araç kusurları, hatalı yol geometrisi, işaretleme eksiklikleri gibi altyapı kusurları ile olumsuz hava koşullarının yarattı̆̆ çevresel faktörlerin de (her ne kadar istatistiklere çok küçük oranlarda yansımış olsalar da) kazaların meydana gelmesinde önemli faktörler olduklarını söylemek mümkündür. Ancak tüm bu faktörlerin kesişim alanında bulunan insan unsurunun; trafikte bilinçli veya bilinçsiz olarak sergiledikleri, alışkanlık haline getirdikleri ve kanıksadıkları hatalı davranışları (aşırı hız, emniyet kemeri takılmaması vb.) çözümlenmesi gereken asıl sorun olarak öne çıkmaktadır (Ekici, 2014, s. 2). Bu açıdan trafik kazalarında insan faktörünün etkisini azaltmaya dönük faaliyetler oldukça önem arz etmektedir.

Trafik kazalarında insan faktörünün etkisini azaltmaya dönük faaliyetlerin başında ise trafik güvenliği kampanyaları (TGK) gelmektedir. Trafik güvenliği kampanyaları (TGK), trafik güvenliğini azaltan, trafikte insan hayatını riske atan durum ve davranışlara karşı, toplumu uyarmak ve sorumluluk bilincini artırmak amacıyla, dikkatle organize edilen, toplumsal bilgileri yayma çabalarının tasarlanıp yürütülmesini kapsayan sosyal iletişim kampanyalarıdır. Trafik güvenliği kampanyaları, trafikte güvenlik sorunlarıyla mücadeleyi hedefle- 
yen çalışmalarda, trafik güvenliği bilincinin geliştirilmesinde, trafikte yeniliklerin ve uygulamalardaki değişikliklerin duyurulmasında halkla ilişkiler yöntemlerini kullanarak önemli katkılar sağlamaktadır (Ekici, 2014, s. 29).

Bu çalışmada; karayolları trafik güvenliğine yönelik düzenlenen kampanyalar, yasal düzenlemeler, denetimler ve hedef grup üzerindeki etki düzeylerinin incelenmesi amaçlanmıştır. Bu kapsamda çalışmanın karayolu trafik güvenliğinin sağlanmasına yönelik gerçekleştirilen faaliyetlerin toplumda bıraktığı etkinin belirlenmesinin yanı sıra ilerleyen süreçte trafik güvenliği kapsamında yürütülecek faaliyetlere de kaynaklık teşkil edeceği düşünülmektedir.

\section{Karayolu Trafik Güvenliğinde Sosyal Kampanyalar}

Toplumların tutumlarına belirli yönde etki ederek kamu yararı sağlamak için insan davranışlarında değişim sağlamak amacıyla toplum önderleri, özel ve devlet kurumları, bireylerin duygularına ve mantıklarına seslenen sosyal kampanyalar oluşturmaya çalışmaktadırlar. Sosyal kampanyaların insanların bilgi düzeyini ve farkındalığını arttırarak tutum ve davranışlarını etkileyebildiği bilinmektedir (Bayraktaroğlu ve İter, 2007). Sosyal kampanyaların davranışsal sonuçları mesajın nitel gücü, kitle iletişim araçlarının dâhil edilmesi, eğitim, mühendislik, uygulama vb. faktörlere göre değişmektedir (Rice ve Atkin, 2012, s. 13).

Yol güvenliğine yönelik kampanyalar; yol kullanıcılarını bilgilendirmeyi, ikna etmeyi ve olumlu yönde tutum ve davranış değişikliği için motive etmeyi amaçlayan ve mesajinı medya kanalları aracılığıyla duyuran projelerdir. Geleneksel medya kampanyalarından farklı olarak karayolu kampanyaları yasal mevzuatlar ve trafik denetimleri gibi ek politikalar ile birlikte yürütülmektedir. Bu kampanyalar "entegre medya kampanyaları" olarak tanımlanmaktadır. Bir meta-analiz çalışmasına göre trafik uygulamaları ile birlikte yürütülen yol güvenliği kampanyaları trafik kazalarını \%8 oranında azaltabilmektedir (Delhomme vd., 1999). Kısaca tanitım ve denetim faaliyetinin bütünleşik yapılmasının trafikte olumlu yönde değişiklik sağlanması bakımından daha etkili olacağı düşünülmektedir.

Toplum yararına bireylerin davranışlarında değişim sağlamaya yönelik bir karayolu trafik güvenliği kampanyası hazırlarken öncelikle hedef kitleyi iyi tanımak, olumlu davranışı öngören faktörleri öğrenmek, istenen yönde davranış değişikliği sağlamak için kuramsal temeli bilmek gerekmektedir. Karayolu güvenliği kampanyaları kıyaslandığında kuramsal temel dikkate alınarak hazır- 
lanan kampanyaların hedeflerine ulaşma bağlamında daha başarılı olduğu bulunmuştur (Delaney, Lough, Whelan, Cameron, 2004). Yol kullanıcilarının davranışlarının alışkanlık haline geldiği düşünüldügünnde, bu davranışların değişmesi aşamalı ve zaman alan bir süreç olacaktır. Bu nedenle davranışın doğasını etkileyen faktörleri bilmek fayda sağlayacaktır. Green, davranışı etkileyen üç etmenden söz etmektedir;

- Davranış öncesi faktörler; Bireyin söz konusu davranışı sergilemesi için motivasyon kaynağı oluşturan tutumlarını, inançlarını ifade etmektedir.

- Etkinleştiren faktörler; Bireyin davranışı gerçekleştirebilmesini sağlayan beceriler şeklinde açıklanmaktadır.

- Güçlendirici faktörler; Davranışın sürekli olmasını sağlayan teşvik edici faktörlerdir (Delaney vd., 2004).

Sosyal kampanyalar, bireylerde tutum ve davranış değişikliğini iki şekilde gerçekleştirmektedirler. Doğrudan değişikliği hedef alan kampanyalarda; bireysel karar alma sürecini etkilemek amaçlanmaktadır. Örneğin alkollü araç kullanma konusunda, sürücüleri alkollü araç kullanmanın muhtemel sonuçları hakkında bilgilendiren, alkollüyken taksi, otobüs vb. araçlarla evlerine dönmelerini öneren ve bu davranışın faydalarını anlatan bir kampanya doğrudan davranış değişikliği oluşturmayı amaçlamaktadır. Dolaylı yolları kullanan kampanyalar ise radyo, televizyon vb. kitle iletişim araçları vasıtasıyla bireylerde farkındalık oluşturmayı hedeflemektedir. Örneğin sigara içmenin içmeyenlere göre olumsuz etkisini temel alan bir kampanya sigara bıraktırma konusunda çok etkili olmayabilir ancak sigara içilen ortamları kısıtlayan yeni bir projeye yol açabilir (Wakefield, Loken, Hornik, 2010). Ancak uzun süredir devam eden, sık sık tekrarlanan, diğer alışkanlıklarla güçlü bağlantısı olan davranışları değiştirmenin zor olacağı düşünülmektedir (Wilde, 1976). Sosyal kampanyaların insanların tutum ve davranışlarına etkisini açıklayan kuramlar şunlardır:

\section{Sosyal Pazarlama Yaklaşımı}

Sosyal pazarlama "planlanmış sosyal değişim" olarak tanımlanmaktadır. Toplum yararına olan yeni düşünceleri, davranışları, normları topluma tanıtarak davranış değişikliği oluşturmayı hedeflemektedir (Wood, 2012). Bir sosyal pazarlama kampanyası hazırlanırken iki tür amaç belirlenmektedir. Geniş amaç; trafik kazalarını azaltmak ve bu kazaların yol açtığı sosyal ve ekonomik maliyetleri düşürmek olabilir. Bu amacı gerçekleştirmeye yönelik atılması ge- 
reken adımlar da diğer amacı oluşturmaktadır. Örnek verilen geniş amaca uygun olarak özel amaç emniyet kemeri kullanımını yaygınlaştırmak olabilir. Sosyal pazarlama kampanyalarından uzun dönemde daha etkili sonuçlar alındığı düşünülmektedir. Bu gibi kampanyaların etkileri kolay ölçülemez ve kampanyalar tüm kamuya yönelik bir sorumluluk almaktadır. Ülkemizde “Dumansız Hava Sahası" bu kampanyalara örnek verilebilir. ABD'de ise gençleri sigaradan uzak tutmayı hedefleyen Truth kampanyası 4 yıl içerisinde gençlerin sigaraya başlama oranlarında \%22'lik bir düşüş sağlamıştır (Evans, 2006). Bir sosyal pazarlama kampanyasında hedef kitlenin davranış değişikliği kararı vermesinde çevresel faktörler ve kişinin yeteneği de etkili olmaktadır. Kişinin yeniliğe adapte olma hızı da önemlidir. İçsel kontrol odaklı olan bireyler yeni davranışları daha kolay benimseyebilirler ve bu kişilere mevcut durumun zararları, yeni durumun faydaları anlatılırsa kampanyanın daha etkili olacağı düşünülmektedir. Dışsal kontrol odaklı bireylere ise başkalarının kendileri hakkında ne düşüneceğinin anlatılmasının işe yarayacağı düşünülmektedir (Bayraktaroğlu ve İlter, 2007).

\section{Sosyal Norm Yaklaşımı}

Sosyal norm yaklaşımına göre davranışlarımızı diğer insanların ne yaptığını anlayarak şekillendirebiliriz. Bu nedenle sosyal norm kampanyalarında diğer insanların ne yaptığını anlatarak davranış değişikliği oluşturmak hedeflenir. Literatürde sosyal norm kampanyalarının yanlış algıları düzelterek davranış değiş̧ikliği oluşturduğu ve sorunları, normları daha belirgin hale getirdiği için davranış değişikliği oluşturduğu şeklinde iki görüş mevcuttur. Sosyal norm yaklaşımı, algılanan normu değiştirerek davranışın da değişmesini amaçlamaktadır. ABD'de alkollü araç kullanmayı engellemek amacıyla alkol aldığı zaman araç kullanmadığını söyleyen ve koruyucu davranışlar öneren genç yetişkinlerin yer aldığı reklam filmi, afişler vs. on beş ilçede çeşitli mekânlarda kullanılmıştır. Alkollü araç kullanma konusunda bir normu benimsetmeyi ve yeni davranış kazandırmayı amaçlayan bu kampanyanın özellikle 21-34 yaş arasında alkollü araç kullanma davranışını azaltma ve koruyucu davranış kazandırma hususlarında etkili olduğu sonucu bulunmuştur. Daha sonraki yıllarda trafik kazalarının nedenleri incelendiğinde kampanya müdahalesinin yapılmadığı kontrol ilçelerinde alkollü araç kullanma sebebiyle gerçekleşen kazaların arttığı, müdahale ilçelerinde ise bu oranın azaldığı görülmüştür. Sosyal norm kampanyasının başarılı olabilmesi için doğru norm bilgisi veren mesajın hedef kitle tarafından görülmesi gerektiği düşünülmektedir (Perkins, Linkenbach, Lewis, Neighbors, 2010). 


\section{Sosyal Bilişsel Kuram}

İnsanların bir şeyi öğrenme sürecinin çevresel, bireysel ve davranışsal etmenlerin etkileşimi sonucunda gerçekleştiğini savunmaktadır. İnsanın sosyal bir varlık olduğu bilgisine dayanarak öğrenmenin, başka bireyleri model alarak ve gözlemleyerek de gerçekleşebileceğini söylemektedir (Gürel, 2014). Bandura (2001)'a göre; medyada kullanılan modelleme yönteminin bilgi ve becerileri eyleme dönüştürmek için gereken öz yeterlilik duygusunu artıracağını söylemektedir. Medya insanlara yeni davranış biçimleri öğretmek ve insanların tercihlerini, inançlarını, beklentilerini değiştirerek bir eylemi gerçekleştirmek için harekete geçmek için motivasyon yaratabilir. Medya insanları dolaylı yoldan da etkileyebilir. Medyada tanıtılan bir kampanya ile karşılaşmamış bir kişi, bu kampanyayı görmüş bir kişiden bilgi alabilir, etkilenebilir. Medya toplumsal etkinin kaynağı olabileceği gibi güçlendirici bir role de sahip olabilir. Bu kurama göre toplumda yeni bir davranış biçiminin yaygınlaşması üç aşamada gerçekleşmektedir. İlk aşama yeni davranışlar hakkında bilgi edinmeyi içermektedir. Daha sonra yeni davranışı uygulamanın benimsenmesi ve sosyal anlamda davranışın yayılması şeklinde gerçekleşmektedir. Yeni davranış daha sonra ya sabit hale gelmekte ya da ortadan kaybolmaktadır (Bandura, 2001).

\section{Planlı Davranış Kuramı}

İnsanların davranışlarını değiştiren süreçleri açıklamaya yardımcı kuramlardan biri de gerekçelendirilmiş eylem teorisidir. Sosyal psikolojide davranışı açıklamak için çokça kullanılan ve Ajzen ve Fishbein (1975)'e göre; tarafından geliştirilen kuram daha sonra genişletilerek planlı davranış kuramı ismini almıştır. Gerekçelendirilmiş eylem teorisi, tutumların sübjektif normlar ile birlikte davranışlara yönelik niyetleri açıklayabileceğini, niyetlerin de davranışları öngörmede etkin rolü olduğunu söylemektedir. Bireyin davranışa yönelik tutumu olumlu olursa, davranışı gerçekleştirme niyetinde olacağını belirtmektedir. Bu kurama algılanan davranışsal kontrol kavramının eklenmesiyle planlı davranış kuramı geliştirilmiştir. Davranışsal kontrol, bireylerin herhangi bir davranışı gerçekleştirmelerinin kendi kontrollerinde olup olmadığıyla ilgili algilamaların ifade etmektedir (Kocagöz ve Dursun, 2010). Bu kurama göre; tutumlar, öznel normlar ve algilanan davranış kontrolü insan davranışını yönlendirebilecek üç unsurdur. Davranışa yönelik tutumlar, sübjektif normlar ve algılanan davranış kontrolü birlikte niyeti, niyet de davranışı etkilemektedir. Kısaca kuram, birey davranışı olumlu algılarsa, davranışa yönelik olumlu bir tutum geliştirirse davranışı destekleme olasıllğının daha yüksek olduğunu söylemektedir. Ayrıca bireyin hayatında önemli olarak gördüğü kişilerin söz 
konusu davranışa yönelik tutumları olumlu ise bu yine bireyi davranışı gerçekleştirmeye iten bir etken olacaktır (Nunkoo ve Ramkissoon, 2010).

\section{Korku Çekiciliği}

Kitle iletişim kampanyalarında korku uyandırma amaçlı riskleri içeren mesajlar kullanılmasına "korku çekiciliği" adı verilmektedir. Geniş̧letilmiş paralel işleme modeli, davranış değişikliğini açıklarken korku çekiciliği ve koruma motivasyon teorisinden yararlanmaktadır. Korku çekiciliği daha çok kamu spotu adıyla bildiğimiz sosyal reklamlarda kullanılmaktadır. Korku çekiciliğinin karayolu güvenliği alanındaki kampanyalarda etkili olduğu söylenmektedir. Loo (1984)'ya göre; ikna edici unsur olarak korkuyu kullanan kampanyalara bakıldığında emniyet kemeri kullanımı ile ilgili orta düzeyde korku içeren kampanyalar daha sık emniyet kemeri kullanımını sağlamaktadır (Nelson ve Moffit, 1988). Ayrıca korku içeren mesajı doğru değerlendiren ve yüksek öz yeterliliğe sahip bireylerin önerilen davranışı üstlenmesi daha olasıdır. Genişletilmiş Paralel İşleme Modeline göre insanları harekete geçiren şey gerçek tehdit değil, algılanan tehdittir. Korkuyu esas alan mesajı olan kampanyaların bireylerin tehdit algısını etkileyerek tehditten kaçınma amacıyla önerilen davranışı yapma noktasında ikna edebileceğini söylemektedir. Korku çekiciliğine maruz kalan bireyler üç şekilde yanıt vermektedir; (1) tepki vermeyebilirler (2) tehlike kontrol tepkisi verebilirler (3) korku kontrol tepkisi verebilirler. İnsanlar tehdidi yüksek olarak algılamazlarsa harekete geçmeyecek ve tepki vermeyeceklerdir (Demirci ve Utkutuğ, 2013). İnsanlar tehdidi yüksek algıladıklarında ise korkuların kontrol yolunu tercih ederlerse reddetme, kaçınma, savunma vs. tepkiler ile korkuyu azaltmaya çalışacaklardır. Eğer tehlike kontrol yolunu seçerlerse inanç, niyet, davranış değişikliği gibi içsel kaynaklarla korkuyu azaltmaya çalışırlar (Maloney, Lapinski, Witte, 2011). Eğer eylem korkuyu azaltmada işe yaradıysa, herhangi bir tehdide yönelik alışılmış bir yanıt haline gelmektedir. Korku çekiciliğinin etkisini inceleyen araştırmalara bakıldığında insanları bir davranışa yöneltmek için korkutmak, istenen davranışı aksi yönde davranılmasına neden olabilmektedir. Öte yandan mesajın içeriği bireyin ilgi alanına giriyorsa ve birey korku veren uyaran ile baş edebileceğine inanıyorsa korkunun ikna ediciliği daha yüksek olmaktadır.

Korku çekiciliği kavramı ile ilişkilendirilebilen koruma motivasyon teorisi ise Rogers tarafından bireylerin sağlık ve güvenlik konularındaki potansiyel tehditlere müdahale etme sürecini anlama amaciyla geliştirilmiştir (Karahoca ve Aksöz, 2019). Bu teoriye göre birey bir tehdit ile karşılaştığında daha önceki 
bilgi ve deneyimlerine dayanarak bir "tehdit değerlendirme sürecine" girmektedir. Bu değerlendirme aşamasında birey mevcut davranışlarla devam etmenin faydalarını ve zararlarını analiz eder. İçsel, dışsal ödülleri ve çevresel faktörleri de hesaba katarak davranış değişikliği hakkında bir karar verir. Bireyin önerilen davranışı benimsemesinde en etkili faktörün öz-yeterlilik olduğu düşünülmektedir (Cismaru, Lavack, Markewich, 2009).

\section{SağlkkModelleri}

Davranış değişikliğinin belirli aşamaları olduğunu savunan transteoretik değişim modeli Prochaska ve DiClemente tarafından geliştirilmiştir. Bu modele göre, davranış değişikliği altı aşamadan oluşan bir karar alma süreci şeklinde gerçekleşmektedir. Modelin aşamaları aşağıda özetlenmektedir;

1. Niyet Öncesi Aşama: Bireyin değişime yönelik bir niyeti yoktur. Davranışı değiştirmesi gerektiğini düşünmez.

2. Niyet Aşaması: Birey davranışın problem oluşturduğunu düşünmeye başlar ancak henüz değiştirme kararı almamıştır.

3. Hazırlık: Bu aşamada birey kendisini değişime hazırlar.

4. Eylem: Birey davranışı değiştirmiştir ancak önceki davranışa dönme riski mevcuttur.

5. Koruma: Yeni davranış alışkanlık haline gelmiştir.

6. Son Bulma: Yeni davranış alışkanlık halini almıştır ve bireyin eski davranışa dönme olasilıği yoktur (Prochaska ve DiClemente, 1983).

Birey davranış değişikliği oluşana kadar bu aşamaları tekrar edebilir, önceki aşamalara geri dönebilir ya da bir sonraki aşamaya geçebilir (Adamos vd., 2009). Davranış değişikliğini zaman alan bir süreç olarak görmesi neticesinde sürücü davranışın değiştirmek için de bu modelden yararlanılmaktadır (Kowalski, Jeznach, Tuokko, 2014). Yol güvenliğine yönelik bir kampanya hazırlarken hedef kitlenin değişim modelinin hangi aşamasında olduğunu bilerek kampanyayı hazırlamak daha başarılı sonuçlar ortaya koyabilir. Örneğin niyet öncesi aşamada olan bir birey davranışının problem oluşturduğunu fark etmediği için bu bireye kampanya mesajını ulaştırma ve davranış değişikliğine ikna etme konusunda ulaşmak güçtür. Ancak niyet aşamasındaki birey yeni bilgilere açıktır ve bilgiler kişiyi ikna ederse bir sonraki aşamaya da geçebilir (Wundersitz, Hutchinson, Woolley, 2010.)

\section{Türkiye'de Karayolu Güvenliği Kampanyalan}

Karayolu güvenliği kampanyaları belirli bir zaman diliminde gerçekleşen, medya organlarını içeren, organize bir şekilde iletişim yöntemlerini kullanarak 
bir grubun ve/veya toplumun yol güvenliğine yönelik tutumlarını, davranışların değiştirmek için bilgilendirmeyi, ikna etmeyi ve motive etmeyi amaçlayan girişimlerdir (Hoekstra ve Wegman, 2011). Son yıllarda Türkiye'de toplumsal farkındalığı attırmak, yaya ve sürücülerde davranış değişikliği gerçekleştirmek ve bir trafik kültürü oluşturmak için kampanyalara önem verilmektedir. Türkiye'de karayolu güvenliğine yönelik kampanyalar, devlet bürokrasisi önderliğinde başlatılmıştır. Türkiye'de son yıllarda trafik güvenliğini sağlamaya yönelik pek çok kampanya, çeşitli kamu kurum ve kuruluşlarını, DSÖ'nün, üniversitelerin desteği ve özel kuruluşların sponsorluğu ile yürütülmektedir. TRT arşiv sitesine bakıldığında trafik güvenliği konulu en eski kampanya 1974 y1lına ait olan trafik eğitim semineri isimli videodur. Dolayısıyla Türkiye'de uzun yıllardan bu yana trafik güvenliğine önem verildiği ve vatandaşların medya aracılığıyla bilgilendirilmeye çalışıldığı görülmektedir.

Ancak toplumda değişikliklerin kabullenilmesi ve içselleştirilmesi için gereken tanıtım, eğitim, bilinçlendirme, yasal düzenleme ve denetimlerin sürekliliğini korumaması İnsanların; kuralları önemsememe, denetim boşluğundan faydalanma, alışkanlık, motivasyon eksikliği gibi nedenlerle kuralları doğru uygulamaması veya uygulamaktan kaçınabilmesine neden olmaktadır (Ekici, 2014, s. 174). Aşağıda Türkiye'de uygulanan karayolu güvenliği kampanyaları hakkında bilgi verilmektedir.

\section{Bu Yolda Hep Birlikteyiz}

Emniyet kemeri kullanımının yaygınlaştırılması, aşırı hız ve seyir halinde cep telefonu kullanımının önlenmesi amaciyla 7 Eylül 2018 yılında başlayan kampanya kapsamında; çocuk ve yetişkinlere yönelik eğitimler verilmiş ve bu konularda denetimler yoğunlaştırılmıştır. Vatandaş, Polis, Jandarma Trafik Denetiminde sloganıla trafikte güvenli davranışlar teşvik edilmiştir. Kampanya kapsamında “Bu Bayram Ben de Trafik Polisiyim, Hatalı Sürücüye Kırmızı Düdük" sloganları ile çocukları trafik denetimlerine dâhil ederek trafik bilincinin erken yaşta oluşmasını sağlama ve aileler üzerinde de çocuklar vasıtasıyla kurallara uyma davranışını arttırmak amaçlanmıştır. Trafik yoğunluğunun arttığı ve trafikte dikkatin daha önemli olduğu dini bayramlar öncesinde kamu spotları ve afişler aracılığıyla kampanya duyurulmuştur. Denetim yapan polis memurları tarafından araçlardaki çocuklara kırmızı düdük, şapka, görev kartları gibi materyaller dağıtılarak çocuklar teşvik edilmiştir. Yapılan değerlendirmelere göre Ramazan Bayramı günlerinde can kaybında \%51, Kurban Bayramı günlerinde ise \%34 azalma sağlanmıştır (İçişleri Bakanlığı, 2020). 


\section{Yaya Öncelikli Trafik}

Karayolları Trafik Kanunun 74. Maddesinde 26 Ekim 2018 tarihinde değişiklik yapılmasıyla ülkemizde yaya öncelikli trafik anlayışı yasal güvence altına alınmıştır. Bu düzenlemenin duyulması ve benimsenmesi için 6 Şubat 2019 tarihinde "Öncelik Hayatın, Öncelik Yayanın" sloganı ile "Trafikte Yaya Önceliği Bilincinin Oluşturulması Kampanyası" başlatılmış, afişler, televizyon ve radyo spotları hazırlanmış, “Öncelik hayatın, Öncelik yayanın” eylemi gerçekleştirilmiştir. Bu kapsamda İçişleri Bakanlığı tarafından 2019 yılı “Yaya Öncelikli Trafik Yılı" ilan edilmiştir. Yaprak ve Kavsıracı tarafından yapılan araştırmada katılımcların \%53'ü 2019 yılının "Yaya Öncelikli Trafik Yılı" ilan edildiğinden haberdar oldukların belirtmişlerdir (Yaprak ve Kavsıracı, 2021). Bütüncül politikalarla kampanyanın üzerinde durulması, yaya önceliği kampanyasının kamuoyu ve medyada gündem olmasını ve birçok kişi tarafından fark edilmesini sağlamıştır. Emniyet Genel Müdürlügü̈ Trafik Daire Başkanlığının web-sitesinde açıkladıkları verilere göre; kampanyanın uygulanmaya başladığ 2019 yılında yaya ölümleri 495'ten 385'e indirilmiş, yaya ölümlerinde $\% 22^{\prime}$ lik bir azalma meydana gelmiştir.

\section{Mobil Trafik Ĕ̆itim Tirn}

2019-2020 eğitim döneminde çocuklara teorik trafik eğitiminin yanı sıra uygulamalı eğitim alabilmeleri için trafik eğitim tırında eğitimciler eşliğinde akülü araçlarla eğitim verilmiştir. "Trafik Dedektifleri Çocuk Eğitim Projesi" kapsamında 7,2 milyon çocuğa, Mobil Trafik Eğitim Tırları ile 53 ilde 526 okulda 37 bin 511 öğrenciye, umuma açık alanlarda 490 bin vatandaşa olmak üzere toplamda 13,5 milyon kişiye trafik eğitimi verilmiştir.

\section{Yaşam Tüneli Trafik Ĕ̆itimi Projesi}

Yol kontrol noktalarına kurulan kapalı alanlarda hem sürücülerin yolculuklarında mola vermesi hem de bu molada trafik eğitimi alması amaçlanmıştır. 2019 yılında 159 bin 752 sürücü bu eğitimi almıştır. Bunun dışında öğretmenler ve şoförlerden oluşan toplam 9 milyon kişi trafik güvenliği eğitimi almıştır (İçişleri Bakanlığı, 2019).

\section{Emniyet Kemeri Kullanimı}

2019 yllında "Kemerin Ses Getirsin" sloganıla başlatılan kampanya emniyet kemeri takılma düzeyini arttırmayı amaçlamaktadır. Kampanya kapsamında çocukların emniyet kemeri kullanma konusunda başkalarını uyardıkları videolarla katılabildikleri bir yarışma düzenlenmiştir. Yaprak ve Kavsıracı 
tarafından yapılan araştırmada; katılımclara emniyet kemeri kullanımına ilişkin sosyal kampanyalar hakkında bilgi sahibi olup olmadıkları sorulmuş ve katılımcıların çoğunluğu $(\% 78,5)$ emniyet kemeri kullanımı ile ilgili sosyal kampanyalardan bilgi sahibi olduklarını belirtmişlerdir (Yaprak ve Kavsıracı, 2021). Emniyet kemeri kampanyalarının uzun bir süredir ve sık tekrarlanıyor olmasının vatandaş nezdinde bir etkililiği olduğu sonucuna ulaşılmaktadır.

\section{Karayolu Trafik Denetimi ve İdari Para Cezaları}

Denetim ve cezaların genel olarak temel amacı, bireylerin kural ihlali gerçekleştirmelerine engel olmaktır. Düzenli bir trafik ortamı için geliştirilen yasal düzenlemeler ve trafik denetimleri, trafik kazaları sonrasında gerçekleşmesi muhtemel can ve mal kayıplarını önlemeyi ve trafik düzenini korumayı hedeflemektedir. Yasal düzenlemeler ve denetimlerin temelinde caydırıclık ön planda tutulmaktadır. Caydırıcılıktaki amaç, kural ihlali gerçekleştiren bireyin ödeyeceği bedeli artırarak olası ihlal girişimlerinin önüne geçmektir. Cezaların etkili olabilmesi için, cezaların açı ve net olması ayrıca bireylerin her an yakalanma riskini algılamaları gerekmektedir (Paternoster ve Bachman, 2001).

Trafik denetim ve cezalarının trafik kurallarına uyum noktasında olumlu yönde katkı sağlayarak trafik ortamında kaza riskini azalttı̆̆ını ifade eden çok sayıda çalışma bulunmaktadır. Bu kapsamda elektronik denetleme sistemlerinin kullanılmaya başlanması sonrasında iki yıllık veriler üzerinden Pérez ve arkadaşlarının Barcelona'da gerçekleştirdiği çalışmada trafik kazalarında azalma yaşandığı tespit edilmiştir (Pérez, Olmo, Tobias ve Borrell, 2007). Hız kameralarının kullanıldığı bir başka çalışma da Christie ve arkadaşları tarafından İngiltere'de yapılmıştır. Hız kameralarının bulunduğu 500 metrelik alanı dikkate alarak yapılan çalışmaya göre; hız kameralarının konumlandırıldığı 500 metrelik alan içinde yaşanan trafik kazalarında \%51 oranında azalma yaşanmıştır (Christie, Lyons, Dunstan ve Jones, 2003). Huvarinen ve arkadaşlarının Rusya ve Finlandiya'da yapmış olduğu araştırmaya göre de trafik denetimleri kazaların \%27 oranında azalmasını sağlamıştır (Huvarinen vd., 2017).

Tablo 2. Türkiye' de bireylerin hız denetimlerini etkili bulma dağılımları

\begin{tabular}{llllll}
\hline \multicolumn{2}{l}{ Katılımci Sayısı } & Evet $\mathbf{( \% )}$ & Kismen $\mathbf{( \% )}$ & Hayır $(\mathbf{\%})$ & Ki-Kare $\left(\chi^{2}\right)$ \\
\hline Genel & $(\mathbf{n}=\mathbf{2 5 0 7})$ & 65,7 & 20,7 & 13,6 & \\
\hline
\end{tabular}

Kaynak: Yaprak ve Kavsiraci, 2021

Yaprak ve Kavsıracı (2021)'nın çalışmasında; “Hız denetimlerini etkili buluyor musunuz?" sorusuna katılımcların \%65,7'sinin hız denetimlerini etkili 
buldukları, \%20,7'sinin kısmen etkili buldukları görülmektedir. Hız denetimlerini etkili bulmayanların oranı $\% 13,6^{\prime}$ dır.

Türkiye'de de kısa vadede trafik kazalarının önlenmesi için denetimler önem kazanmaktadır. Bu çerçevede kolluk görevlilerinin geleneksel denetimlerinin ${ }^{7}$ yanında maket araç/polis uygulamaları da son yıllarda trafik kazalarınin azaltılmasında önemli rol oynamıştır. 2015-2020 yılları arasında trafik kazalarındaki can kayıpları \%35 oranında azalmıştır (İcișleri Bakanlığı, 2019). Yaprak ve Kavsıracı (2021)'nın çalışmasında; maket / model polis araçlarının hız limitlerine uygun hareket edilmesi konusunda yardımcı olduğunu düşünüyor musunuz?" sorusuna katılımcların \%63,4'ü maket/model polis araçlarının etkili olduğunu, \%21,4'ü kısmen etkili olduğunu düşündüklerini belirtmektedirler. Maket/model polis araçlarının etkili olduğunu düşünmeyenlerin oranu ise $\% 15,2^{\prime}$ dir.

Trafikteki denetimlerin etkinliğini arttırmak için teknolojik imkânlar da mümkün olduğunca kullanılmaktadır. Hava araçlarının (helikopter, drone) kullanımı ile trafiğin yoğun olduğu yerlerde kolaylıkla denetim sağlamaktadır. Emniyet Genel Müdürlüğü hem helikopter hem de drone ile havadan trafik denetimler gerçekleştirmektedir. 2020 yllının ilk 5 aylık sürecinde; helikopterler ile 522 saat uçuş gerçekleştirilmiş ve 3.170 kural ihlali tespit edilmiş, drone hava taşıtları ile 3.946 saatlik uçuş sonunda 22.651 kural ihlali tespit edilmiş ve cezai işlem uygulanmıştır (Emniyet Genel Müdürlüğü, 2020). Yaprak ve Kavsıracı (2021)'nın çalışmasında; son dönemlerde sık kullanılan havadan denetim (helikopter, drone ile) yöntemlerini etkili buluyor musunuz?" sorusuna kattlımcların \%69,9'u havadan denetim yöntemlerini etkili bulduklarını, \%21,2'si kısmen etkili bulduklarını belirtmişlerdir. Havadan denetim yöntemlerini etkili bulmayanların oranı ise $\% 9^{\prime}$ dur. Trafik birimlerinde teknolojik uygulamaların trafik güvenliğine katkı sağladığını düşünüyor musunuz?" sorusunda ise katılımcıların \%66,5'i teknolojik uygulamaların trafik güvenliğine katkı sağladığını, \%25'i kısmen katkı sağladığını düşündüklerini belirtmektedir. Teknolojik uygulamaların trafik güvenliğine katkı sağladığını düşünmeyenlerin oranı yalnızca \%8,5'dir. (Yaprak ve Kavsıracı, 2021).

\footnotetext{
${ }^{7} 2009$ ile 2018 yılları arasında trafikte denetlenen araç ve sürücü sayılarının karşılaştırması incelendiğinde, denetim sayılarında önemli bir artış gözlenmektedir. Yaprak ve Akbulut (2019) tarafından yayınlanan rapora göre, 2009 yılında denetlenen araç ve sürücü sayısı 15.814.317 iken bu sayı 2018 yılına gelindiğin \%120 artarak 34.896.154 sayısına ulaşmıştır. 2018 yılında yapılan trafik denetimlerinde en büyük payı emniyet kemeri denetimleri (\%40), yük taşıyan araçların ve sürücülerin denetimi (\%20) ve alkol denetimi (\%16) almaktadır (Yaprak ve Akbulut, 2019).
} 
Emniyet Genel Müdürlüğü bünyesinde, Polis Amirleri Eğitim Merkezi (PAEM), Polis Meslek Yüksek Okulları (PMYO), Polis Meslek Eğitim Merkezleri'nden (POMEM) 2018 yllından itibaren toplam 5.934 personel mezun olduktan sonraki ilk atamaları doğrudan trafik birimlerine yapılmıştır (Trafik Güvenliği Strateji Belgesi, 2021). “Atamalardan önce şehirlerarast yollarda her 20 kilometreye 1 trafik ekibi düşerken, bu mesafe 16 kilometreye inmiş, önceden 19 bin kişiye bir trafik ekibi düşerken bu sayının da 16 bine indirilmesi sağlanmıştır." (Trafik Güvenliği Strateji Belgesi, 2021). Yaprak ve Kavsıracı (2021)'nın çalışmasında, Son dönemlerde trafik birimlerinde görevlendirilen genç polis memurlarının görevin yürütülmesine pozitif bir enerji kattı̆ını düşünüyor musunuz?" sorusuna katılımcların \%63'ünün genç polis memurlarının görevin yürütülmesine pozitif bir enerji kattığını düşündükleri, \%22,4'ünün k1smen pozitif bir enerji kattığını düşündükleri görülmektedir. Genç polis memurlarının görevin yürütülmesine pozitif bir enerji kattı̆ını düşünmeyenlerin oranı \%14,6'dır. Ayrıca katılımcların \%70,8'i trafik birimlerinde çalışan personelin giydiği fosforlu renkli polis kıyafetlerinin trafik güvenliğine katkı sağladığını, \%21,9'u kısmen katkı sağladığını düşünmektedir. Fosforlu renkli trafik polisi kıyafetlerinin trafik güvenliğine katkı sağladığını düşünmeyenlerin oranı ise \%7,4'tür.

2007 yılında Norveç'te yapılan bir araştırmada; emniyet kemeri takmayanlara verilen cezaların arttırılması ile birlikte emniyet kemeri takma oranlarında kentsel alanlarda \%10, kırsal alanlarda ise \%2,5-5 arası artış saptanmıştır. (Elvik ve Christensen, 2007, s. 689-695). Benzer bir korelasyon Amerika Birleşik Devletleri'nde de bulunmuştur. Cezalardaki artış ile emniyet kemeri takma oranlarında \%3 ile \%4 arasında artış gözlemlenmiştir (Nichols ve Ledingham, 2008). Yapılan bir başka araştırmada da hız ihlalinde bulunanların ödediği cezaların arttırılması ile yeniden hiz ihlalinde bulunma oranlarında \%6,3 azalma saptanmıştır. Amerika ve İsrail'de yapılan araştırmada; kırmızı ışıkta geçenlere verilen trafik cezasındaki artışın, kırmızı ışıkta geçme oranlarında ortalama \%5 düşüş sağladığı belirtilmektedir. Türkiye'de 2015 yılında yapılan bir araştırmada trafik kazaları sonucunda gerçekleşen ölüm oranlarında düşüşü sağlayan belirleyici faktörün trafik cezaları olduğu ifade edilmiştir. (Sümer ve Kaygisiz, 2015, s. 200).

Tablo 3. Türkiye' de bireylerin trafik idari para cezalarını caydırıcı bulma dağılımları

\begin{tabular}{llllll}
\hline Katılımci Sayısı & Evet (\%) & Kismen (\%) & Hayır (\%) & $\begin{array}{l}\text { Ki-Kare } \\
\left(x^{2}\right)\end{array}$ \\
\hline Genel & $(\mathbf{n = 2 5 3 1 )}$ & 47,7 & 22,5 & 29,8 & \\
\hline
\end{tabular}

Kaynak: Yaprak ve Kavsirac1, 2021. 
Yaprak ve Kavsıracı (2021)'nun çalışmasında; "trafik idari para cezaları caydırıcı mı?" sorusuna katılımcıların $\% 47,7^{\prime}$ sinin trafik idari para cezalarını caydırıcı, \%22,5'inin kısmen caydırıcı buldukları görülmektedir. Trafik idari para cezalarını caydırıc bulmayanların oranı \%29,8'dir. Aynı çalışmada katılımcıların \%76'sı kanun maddelerinde yapılan değişikliklerin trafik güvenliği konusunda etkisinin olumlu yönde olduğunu belirtirken, \%20,5'i herhangi bir etkisi olmadığın belirtmiştir. Kanun maddelerinde yapılan değişikliklerin etkisinin olumsuz yönde olduğunu düşünenlerin oranı ise yalnızca \%3,5'tir. 2015 y1lında Sümer ve Kaygisiz tarafından yapılan bir araştırmada; trafik kazalarına bağlı ölüm oranlarında azalmayı sağlayan etkili faktörler üzerinden karşılaştırma yapıldığında, cezaların rutin denetimlerden daha etkili olduğu belirtilmiştir (Sümer ve Kaygisiz, 2015).

Trafik kazaları temel olarak insan, araç ya da çevre kusurlarından kaynaklanmaktadır. Bu bileşenler içerisinde insan kusuru, trafik kazalarının gerçekleşmesinde en büyük orana sahiptir. Yapılan araştırmalarda trafik cezalarının ve denetimlerin artturılmasıyla trafikte insan davranışlarında olumlu yönde değişiklik sağlanacağı noktasında elde edilen bulgular bulunmaktadır. Trafik cezalarındaki artışın etkinliğini sağlayan ana faktör, kişilerin trafikte algıladığ1 yakalanma riskidir. Bu nedenle trafik cezaları ve denetimlerinin bütüncül politikalar çerçevesinde birlikte ele alınması gerekmektedir.

Tablo 4. Trafik denetimlerinin trafik güvenliğine katkı sağladığını düşünme dağılımları

\begin{tabular}{lllll}
\hline Katılımcı Sayısı & Evet (\%) & Kismen (\%) & Hayır (\%) & Ki-Kare
\end{tabular}

$\left(\chi^{2}\right)$

\begin{tabular}{lllll}
\hline Genel $\quad(\mathbf{n}=\mathbf{2 5 9 0})$ & 79,2 & $\mathbf{1 5 , 4}$ & 5,4
\end{tabular}

Kaynak: Yaprak ve Kavsırac1, 2021.

Yaprak ve Kavsıracı (2021)'nun çalışmasında; trafik denetimlerinin trafik güvenliğine katkı sağladığını düşünüyor musunuz?" sorusuna katılımcıların $\% 79,2$ 'sinin trafik denetimlerinin trafik güvenliğine katkı sağladığını düşündüğü, \%15,4'ünün kısmen katkı sağladığını düşündüğü görülmektedir. Trafik denetimlerinin trafik güvenliğine katkı sağladığını düşünmeyenlerin oranı ise yalnızca \%5,4'tür (Yaprak ve Kavsırac1, 2021).

İnsanların düşünceleri duygularını, duyguları da davranışlarını etkilemektedir. Olayları algılama biçimimiz, duygularımızı ve davranışlarımızı büyük oranda belirlemektedir. İnsanların duygusal tepkileri hem iç (düşünceler, duygular) hem de dış faktörler tarafından belirlenmektedir. Bireylerin yasal düzenlemelere verdiği duygusal, bilişsel ve davranışsal yanıtları incelemekle düzenlemelerin etkinliği, caydırıcılı̆̆ı hakkında bilgi sahibi olmak mümkündür. 


\section{Tartışma ve Sonuç}

Karayolu trafik güvenliği, insan, yol ve taşıtın birbiriyle etkileşimi sırasında meydana gelebilecek sorunlara çözüm yolları arama ve sorunların oluşmasını önlemeye yönelik gerçekleştirilen sosyal, teknik, yasal ve uygulamalı tüm çalışmaları kapsamaktadır. Bu noktada kısa vadede trafik kazalarının azaltılması için insan davranışlarını olumlu yönde değiştirebilecek bütüncül politikalar öncelikli olarak değerlendirilmektedir.

Türkiye'de trafik güvenliğine yönelik sosyal kampanyalar ve kamu spotlarının geneli göz önünde bulundurulduğunda; hem içerik hem de görsel olarak en akılda kalıcı olanlarının yaygın bir zamanda sürdürülen, gündemde tutulan ve yöneticiler tarafindan dile getirilen, denetim gibi unsurlarla desteklenen kampanyalar olduğu göze çarpmaktadır. Günümüzde kampanyalara ilişkin görseller, afiş ve logolar, videolar televizyondan ziyade sosyal medya aracillğıyla fark edilmektedir. Ayrıca yolların görülebilir noktalarına bulunan billboard ve led ekranların da verimli yerler olduğu ve kişiler üzerinde uyarıcı etkiye sahip olduğu unutulmamalıdır.

Kamu spotları insanlarda bir farkındalık yaratmak ve kuralları hatırlatmak bakımından oldukça faydalıdır. Kamu spotlarının verimliliğinin arttırılması için kural ihlallerinin nelere sebep olabileceğine dair çarpıc görüntüler; aile bireyleri, ailevi ilişkiler ve duygusal kurgular; çocukların ilgisini çekecek unsurların kamu spotlarında yer alması önerilmektedir. Bu tarz kamu spotlarının akılda kalma ve bir davranış değişikliğine yol açma konularında daha etkili olacağı düşünülmektedir. Bu konuda çocuklara yönelik kamu spotlarına özel bir önem atfedilmelidir. Bunun başlıca sebebi çocukların trafik kurallarına ilişkin bilgileri içselleştirebilmesi ve böylelikle gelecekte bilinçli bireyler olarak trafikle ilgili süreçlere katılabilmeleridir. İkincisi ise çocukların ebeveynleri üzerinde denetleyici ve uyarıc bir etkilerinin olmasıdır:

Çocuklara eğitici, uyarıc ve denetleyici görevler atfedilmesinin başlıca sebebi ise belirli bir yaşı üzerindeki insanlara, trafik ve trafik güvenliğiyle ilgili bir eğitim almamaları sebebiyle, kamu spotları ya da kampanyalarla ulaşmanın ve davranışlarını etkilemenin çok da mümkün olmayacağı yönündeki kanaatlerdir. Türkiye'de "trafik kültürü" ya da "trafik ahlakı" olarak nitelendirilen olgunun tam anlamıyla oluşmadığı değerlendirildiğinde; trafik güvenliğine yönelik kampanyaların anaokulu döneminden başlayan ve yetişkinlik döneminde de devam eden bir eğitim sürecine odaklanması gerektiğini söylemek mümkünüdür. 
Trafik güvenliğine yönelik yürütülecek kampanyalarda bir diğer husus ise kampanyalar arasında ve paydaşlar arasında bir koordinasyonun olmasının gerekliliğidir. Yürütülecek olan kampanyaların ulusal anlamda etkili olabilmesi için hem ilgili tüm kamu kurumlarının hem de sivil toplum kuruluşlarınun sorumluluk alması gerekmektedir. Bu aşamada iş birliği ve ortak bir çatı kurulması oldukça önemli görülmektedir. Kampanyaların hangi alanlarda ve nasıl uygulanacağına ilişkin karar sürecinde kaza, ihlal ve ilgili bireylere ait verilerin kullanılması önerilmektedir. En çok kaza, ihlal yaşanan durumlar ve bu durumlara yol açan bireylere ait istatistiklerden hareketle geliştirilmiş, profesyonel olarak amaca yönelik uygulanacak olan kampanyaların daha başarılı olacağı düşünülmektedir. Böylelikle kaza ve ihlallerde anlamlı bir düşüş olup olmayacağı ve kampanyaların etkililiği gözlemlenebilir hale gelecektir.

Trafik denetimleri ve idari para cezaları genel anlamda sürücü davranışları üzerinde etkili olarak trafik güvenliğine katkı sağlamaktadır. Fakat bu katkının kayda değer bir şekilde gerçekleştirilebilmesi için denetimlerin yaygın ve sürekli olarak yapılması gerekmektedir. Denetimlerin, eğitim ve diğer bilgilendirme ve bilinçlendirme faaliyetleriyle desteklenmedikçe, denetim konusundaki gelişmelerin tam anlamıyla başarıya ulaşması beklenemez.

Trafik denetimleri, trafik içerisinde yer alan insanların davranışlarını değiştirmesi ve kurallara uyması bakımından trafik güvenliğine katkı sağlamaktadir. Elektronik denetleme sistemleri ve drone cihazlarını kullanılması denetimlerin etki alanını ve yoğunluğunu arttırmaktadır. Polis uygulamalarında elektronik sorgulama araçlarının kullanılması, trafiğin aksamasını ve tıkanmaları, insanların vakit kaybetmesini engellemekte; polisin daha çok sorgulama yapmasını sağlamaktadır.

Denetimlerde spesifik olarak tek bir ihlal yerine tüm unsurları kapsayan bütüncül uygulamalar gerçekleştirilmelidir. Yalnızca trafik polisleri değil diğer polisler de bu denetimleri gerçekleştirmelidir. Noktasal denetlemelerin trafik üzerindeki etkisi oldukça düşük bulunmaktadır. Polis uygulamalarının ya da elektronik denetimlerin yerinin bilinmesi, trafikteki sürücülerin birbirlerine uyarıda bulunması denetimlerin etkililiğini yitirmesine neden olmaktadır. $\mathrm{Bu}$ sebeple hız koridoru, plaka okuyucular, drone araçların kullanılması, yalnızca hız sınırı değil tüm denetimleri kapsayabilecek teknolojik sistemlerin faaliyete geçirilmesi gerekmektedir.

Denetimlerin yaygınlığı, sıklığı arttırılmalı ve bir süreklilik sağlanmalıdır. İnsanlar her an ve her yerde denetlenebilme ihtimalleri olduğunu hissederek trafikte bulunmalıdır. Denetimlerde yalnızca cezai işlem uygulamak yerine, 
kurallara uyan sürücülere sembolik hediyelerle ya da sözlü olarak tebrik ve teşekkür edilmelidir. Bu tarz uygulamaların, özellikle taşrada, trafik kurallarına uymayı ve sürdürülebilirliği arttıracağı düşünülmektedir.

Trafikteki bireylerin her zaman denetim ve yaptırım riskini hissetmeleri gerekmektedir. Bunun için denetimlerin sayısının ve denetim yerlerinin arttırılması, tüm ihlalleri tespit edebilecek şekilde ve bütüncül olarak yapılması, teknolojik imkânlardan güncel olarak faydalanılması önerilmektedir.

İnsanların tutum ve davranışlarında değişiklik gerçekleşmesi ve bu değişikliğin başkaları tarafından algılanması uzun vadeli bir sürece ihtiyaç duymaktadır. Dolayısı yeni sayılabilecek değişikliklerin etkisinin algılanmasına ilişkin tutumların da önümüzdeki süreçte daha net olarak sonuçlara olumlu şekilde yansıyacağı düşünülmektedir. 


\section{Extended Abstract}

\section{Social Campain, Traffic Control, Traffic Penalties Which is implemented for Road Traffic Safety and Effections of Individuals}

\author{
Ozan Kavsirac1 \\ ORCID: 0000-0001-6351-3725
}

\author{
Mehmet Demirbaş \\ ORCID: 0000-0002-9760-1130
}

Sena Tine

ORCID: 0000-0002-9526-0176

The main purpose of the road transport system is to move people and goods from one place to another efficiently and safely. However, in cases where traffic safety cannot be provided at a sufficient level, the material and moral bills that arise after traffic accidents reach very high proportions in terms of both individuals and society. The factors that cause traffic accidents and endanger traffic safety are grouped under three main headings: vehicle, road and environment, human and legal-administrative factors. The human element in the intersection of all these factors; faulty behaviors that they consciously or unconsciously exhibit in traffic, make a habit of and get used, stand out as the main problem that needs to be resolved. In this respect, the activities that aim to reducing the impact of the human factor in traffic accidents are very important.

The road traffic safety studies include training, inspection, legal regulation and engineering studies for the purpose of searching for solutions to the problems that occur during the interaction of people, roads, vehicles and developing suggestions to prevent the occurrence of problems. In this context, many institutions or organizations continue to work in order to ensure road traffic safety. Campaigns intended for road safety; These are projects that aim to inform, persuade and motivate road users for positive attitude and behavior change and announce their message through media channels. Campaigns intended for road are carried out with additional policies such as legal regulations and traffic controls, on the contrary, traditional media campaigns. In Turkey, campaigns have been given importance in recent years in order to 
increase social awareness, to change the behavior of pedestrians and drivers, and to create a traffic culture. Campaigns for road safety in Turkey started under the leadership of the state bureaucracy. In recent years, many campaigns aimed at ensuring traffic safety in Turkey have been carried out with the support of various public institutions and organizations, WHO (World Health Organization), universities and sponsorship of private institutions.

Considering the general social campaigns and public service advertisements for traffic safety in Turkey; Both in content and visually, it is striking that the most memorable ones are the campaigns that are carried out at a extensive time, kept on the agenda, uttered by the managers, and supported by factors such as traffic control. In today's world, images, banners, logos and videos related to campaigns are noticed through social media rather than television. In addition, it should not be forgotten that billboards and led screens located at the visible points of the roads are also productive places and have a stimulating effect on people. In order to make campaigns effective in the national sense, both all relevant public institutions and non-governmental organizations should take responsibility. At this stage, cooperation and establishing a common roof become very important. It is recommended to use data on accidents, violations and relevant individuals in the decision process regarding which areas and how the campaigns will be implemented. In order to fully understand the phenomenon described as "traffic culture" or "traffic morality" in Turkey; It is possible to say that traffic safety campaigns should focus on an education process that starts from kindergarten and continues into adulthood.

The main purpose of traffic controls and fines in general is to prevent individuals from committing violations of rules. Legal regulations and traffic controls developed for a regular traffic environment aim to prevent possible loss of life and property after traffic accidents and to maintain traffic order. On the basis of legal regulations and controls, deterrence is prioritized. The purpose of deterrence is to prevent possible violation attempts by increasing the price to be paid by the individual who violates the rules. In order for the penalties to be effective, the penalties must be clear and precise, and individuals must perceive the risk of being caught at any moment.

Traffic controls should be done widely and continuously. Unless controls are supported by training, other informative and awareness activities, developments in traffic control cannot be expected to be fully successful. The use of electronic control systems and drone devices increases the scope and in- 
tensity of controls. The use of electronic interrogation tools in police applications prevents traffic disruptions and blockages, and losing of time; It allows the police to make more inquiries. During the controls, not only should the drivers be fined, but also the drivers who comply with the rules should be congratulated and thanked with verbal or symbolic gifts. It is thought that such practices will increase compliance and sustainability, especially in rural areas.

A change in people's attitudes and behaviors and the perception of this change by others requires a long-term process. Therefore, it is thought that the attitudes towards the perception of the impact related to the changes that can be considered new will be reflected more clearly on the results in the coming period.

\section{Kaynakça/References}

Alat, A. (2014). Trafik kazalarının çocuklar üzerindeki etkileri ve trafik polislerinin çocukları koruyucu görevleri. (Yayımlanmamış yüksek lisans tezi). Polis Akademisi, Ankara.

Bandura, A. (2001). Social cognitive theory of mass communication. Media psychology, 3(3), 265-299. https://doi.org/10.1207/S1532785XMEP0303_03.

Bayraktaroğlu, G. ve İlter, B. (2007). Sosyal pazarlama: engeller ve öneriler. Ege Akademik Bakıs, 7(1), 117-132.

Christie, S.; Lyons, R; Dunstan, F. ve Jones, S. (2003). Are mobile speed cameras effective? a controlled before and after study. Injury Prevention. 9(4), 302-306. https://doi.org/10.1136/ip.9.4.302

Cismaru, Lavack ve Markewich, E. (2009). Social marketing campaigns aimed at preventing drunk driving. International Marketing Review, 26(3), 402-402. https://doi.org/10.1108/02651330910960799

Delaney, A., Lough, B., Whelan, M. ve Cameron, M. (2004). A review of mass media campaigns in road safety. 25 Ekim 2020 tarihinde https://www.monash.edu/_data/assets/pdf_file/0012/217200/A-review-of-mass-media-campaigns-in-road-safety.pdf adresinden erişildi.

Delhomme, P., Vaa, T., Meyer, T., Goldenbeld, C., Jaermark, S., Christie, N. ve Rehnova, V. (1999). deliverable 4: evaluated road safety media campaigns: an overwiev of 265 evaluated campaigns and some meta-analysis on accidents. Status (Public). Gadget Project Contract No Ro-97-Sc. 2235.

Demirci, A. ve Utkutuğ, Ç. P. (2013). Sigara ambalajı üzerindeki görsel uyariların etkileri. Üçüncü Sektör Sosyal Ekonomi, 48(1), 38-48.

Demiröz, A. (2006). Trafik kazalarının nedenleri ve önlenmesinde halkla ilişkilerin önemi. (Yayımlanmamış doktora tezi). Gazi Üniversitesi, Ankara. 
Dünya Sağlık Örgütü [DSÖ]. (2018). World health organization global status report on road safety. 25 Ekim 2020 tarihinde http://apps.who.int/iris/bitstream/handle/10665/277370/WHO-NMH-NVI-18.20-eng.pdf?ua=1 adresinden erişildi.

Ekici, A. (2014). Trafik güvenliği kampanya modeli ve uygulaması. (Yayımlanmamış doktora tezi) Gazi Üniversitesi, Ankara.

Elvik, R. ve Christensen, P. (2007). The deterrent effect of increasing fixed penalties for traffic offences: the Norwegian experience. Journal of Safety Research, 38(6), 689-695. https://doi.org/10.1016/j.jsr.2007.09.007

Emniyet Genel Müdürlüğü. (2020). Havadan trafik denetimi gerçekleştirildi. 4 Kasım 2020 tarihinde https://www.egm.gov.tr/havadan-trafik-denetimi-gerceklestirildi adresinden erişildi.

Evans, W. D. (2006). How social marketing works in health care. Bmj, 332(7551), 1207-1210. https://doi.org/10.1136/bmj.332.7551.1207-a

Furan, Z. (2019). Trafik güvenliğine yönelik yürütülen sosyal sorumluluk kampanyaları: Konya örneği. (Yayımlanmamış yüksek lisans tezi). Selçuk Üniversitesi, Konya.

Gürel, R. (2014). Sosyal pekiştireçlerin ve model davranışlarının, çocukların ahlaki yarg1larının şekillenmesindeki etkisi (Bandura örneği). Değerler Eğitimi Dergisi, 12(28), 101-119.

Hoekstra, T. ve Wegman, F. (2011). Improving the effectiveness of road safety campaigns: Current and new practices. IATSS Research, 34(2), 80-86.

İçişleri Bakanlı̆̆ı. (2020). Bir yol hikayesi. 25 Ekim 2020 tarihinde https://www.icisleri.gov.tr/bir-yol-hikayesi adresinden erişildi.

Huvarinen, Yuha; Svatkova, Elena; Oleshchenko, Elena ve Pushchina, Svetlana. (2017). Road safety audit. Transportation Research Procedia, 20(2017), 236-241. https://doi.org/10.1016/j.trpro.2017.01.061

İçişleri Bakanlığı. (2019). Türkiye trafik güvenliği denetimi. 4 Kasım 2021 tarihinde https://www.icisleri.gov.tr/turkiye-trafik-guvenligi-denetimi-8 adresinden erişildi.

Karahoca, D. ve Aksöz A. M. (2019). Kişisel akıllı teknolojilerin sağlık amaçlı kullanımlarının kabulünün değerlendirilmesi. Electronic Turkish Studies, 14(2), 493-519. http://dx.doi.org/10.7827/TurkishStudies.14914

Kocagöz, E. ve Dursun, Y. (2010). Algılanan davranışsal kontrol, Ajzen'in teorisinde nasıl konumlanır? alternatif model analizleri. Karamanoğlu Mehmetbey Üniversitesi sosyal ve ekonomik araştırmalar dergisi, 2(2010), 139-150.

Kowalski, K., Jeznach, A. ve Tuokko, H. A. (2014). Stages of driving behavior change within the transtheoretical model (TM). Journal of safety research,50, 17-25. https://doi.org/10.1016/j.jsr.2014.01.002

Maloney, E. K., Lapinski, M. K. ve Witte, K. (2011). Fear appeals and persuasion: A review and update of the extended parallel process model. Social and personality psychology compass, 5(4), 206-219.

Nelson, G. D. ve Moffit, P. B. (1988), Safety belt promotion: theory and practice. accident analysis and prevention, 20(1), 27-38 
Nichols, J. L. ve Ledingham, K. (2008). the impact of legislation, enforcement, and sanctions on safety belt use. 30 Ekim 2020 tarihinde https:/www.trb.org/Publications/Blurbs/159627.aspx adresinden erişildi.

Nunkoo, R. ve Ramkissoon, H. (2010). Gendered theory of planned behaviour and residents' support for tourism. Current issues in tourism, 13(6), 525-540.

Paternoster, R. ve Bachman, R. (Der.) (2001). Explaining criminals and crime: essays in contemporary criminological theory. Oxford, UK: Oxford University Press.

Pérez, K., Marí-Dell'Olmo, Tobias, A., ve Borrell, C. (2007). Reducing road traffic injuries: effectiveness of speed cameras in an urban setting. American journal of public health. 97(9), 1632-1637.

Perkins, H. W., Linkenbach, J. W., Lewis, M. A. ve Neighbors, C. (2010). Effectiveness of social norms media marketing in reducing drinking and driving: A statewide campaign. Addictive behaviors, 35(10), 866-874.

Prochaska, J. O. ve DiClemente, C. C. (1983). Stages and processes of self-change of smoking: Toward an integrative model of change. Journal of consulting and clinical psychology. 51(3), 390-395.

Rice, R. E. ve Atkin, C. K. (Der.). (2012). Public communication campaigns. SAGE publications.

Sümer, N. ve Kaygısız, Ö. (2015). Türkiye'de denetleme, cezalar ve trafik güvenliği göstergeleri arasındaki ilişkiler: 2008-2012 yılları analizi. Türkiye halk sağhl̆̆ı dergisi, 13(3), 193-205.

Trafik Güvenliği Strateji Belgesi. (2021). Karayolu trafik güvenliği strateji belgesi 2021-2030. 4 Kasım 2021 tarihinde http://trafik.gov.tr/kurumlar/trafik.gov.tr/01-Haberler/032021/2021_2030-Karayolu-Trafik-Guvenligi-Strateji-Belgesi.pdf adresinden erişildi.

Türkiye İstatistik Kurumu [TÜİK]. (2020). Karayolu trafik kaza istatistikleri. 4 Kasım 2021 tarihinde, https://data.tuik.gov.tr/Bulten/Index?p=Karayolu-Trafik-Kaza-Istatistikleri-2019-33628 adresinden erişildi.

Wakefield, M. A., Loken, B. ve Hornik, R. C. (2010). Use of mass media campaigns to change health behaviour. The Lancet, 376(9748), 1261-1271.

Wilde, G. J. (1976). Social interaction patterns in driver behavior: An introductory review. Human factors, 18(5), 477-492.

Wood, M. (2012). Marketing social marketing, Journal of social marketing, 2(2), 94-102.

Wundersitz, L. N., Hutchinson, T. P. ve Woolley, J. E. (2010). Best practice in road safety mass media campaigns: a literature review. Social psychology, 5, 119-186.

Yaprak, Ş. ve Akbulut, M. A. (2019). Trafik kaza istatistikleri raporu. Ankara: Polis Akademisi Yayınları.

Yaprak, Ş. ve Kavsıracı, O. (2021). Trafik güvenliği etki analizi raporu. Ankara: Polis Akademisi Yayınları.

Yasak Y. ve Kılıç N. (2014). Psikolojik değerlendirme için psikoteknik değerlendirme merkezine başvuran sürücülerin trafiğe ilişkin kişilik özellikleri ve tutumları. 5. Trafik Güvenliği Sempozyumu ve Sergisi Bildiriler Kitabı, İstanbul. 